Claves. Revista de Historia, Vol. 2, $\mathrm{N}^{\mathrm{o}} 3$

Montevideo, Julio-Diciembre 2016

(pp. 45-71) ISSN 2393-6584

\title{
Dibujos y acuarelas, estampas y prensa. \\ Los artistas como reporteros y publicistas \\ en Montevideo (1830-1851)
}

Ernesto Beretta García

Universidad de la República

Museo Histórico Nacional

Recibido: 10/10/2016

Aceptado: 19/11/2016

\section{Resumen}

Entre 1839 y 1851 se publicaron en Montevideo los primeros periódicos prolíficamente ilustrados. Si bien sus estampas tuvieron una fuerte tendencia publicitaria y política en el contexto de la Guerra Grande, a veces la misma quedó equilibrada por la veracidad del asunto representado y el detalle con el que fue tratado. Estas páginas con imágenes se sumaron a la producción de estampas sueltas, que se inició hacia 1830. Para este tiraje de láminas, resultaban fundamentales dibujos y acuarelas, realizados por los artistas al momento de producirse los acontecimientos, originales en los que se consignaban referencias escritas para precisar y conservar el detalle de la información. En este campo, Montevideo se sumó entonces a las tendencias de la prensa ilustrada occidental y al tiraje de estampas mediante nuevas técnicas, en síntesis, a una nueva cultura visual.

Palabras clave: Estampas, artistas-reporteros, Montevideo, Guerra Grande

\section{Drawings and watercolors, prints and press. Artists as reporters and publishers in Montevideo (1830-1851)}

\section{Abstract}

Between 1839 and 1851 the first newspapers were published in Montevideo, which include illustrations as a habitual resource in their numbers. Although its prints had a strong advertising and political tendency in the context of the Great War, sometimes it 
was balanced by the veracity of the subject represented and the detail with which it was treated. These pages with images were added to the production of loose prints, which began around 1830. For these sheet prints, were fundamental drawings and watercolors produced by the artists at the time of the recorded events, original in which written references were recorded to specify and preserve the detail of the information. In this field, Montevideo then joined the trends of the western illustrated press and the printing of prints using new techniques, in synthesis, a new visual culture.

Key words: prints, artists-reporters, Montevideo, Guerra Grande

\section{Introducción}

A partir de la experiencia dada en el Estado Oriental durante la primera mitad del siglo XIX, este artículo se propone abordar el rol que cumplieron las imágenes en un contexto concreto, aproximarnos a cómo la sociedad o algunos sectores se sirvieron de ellas y las emplearon con fines determinados, desde los puramente artísticos o decorativos hasta los informativos, publicitarios y proselitistas. Se analiza asimismo la incipiente incorporación de la sociedad oriental a una forma moderna de generación y transmisión de la información mediante la combinación de textos e imágenes de tiraje amplio (periódicos, folletos y libros ilustrados, y estampas). Dicha participación fue posible por el advenimiento de tecnologías específicas, de aplicación relativamente fácil. Esta cuestión resulta relevante para el caso del Estado Oriental, pues no será hasta después de 1830 que las imágenes en general (pinturas, acuarelas, estampas en sus distintas modalidades, cosmoramas y dioramas) se conviertan en piezas de uso y circulación habitual, y no solo a nivel de los sectores altos de la sociedad montevideana. ${ }^{1}$ Las series de imágenes que comenzaron a ver la luz en el segundo cuarto del siglo XIX alcanzaron una difusión y una accesibilidad desconocida antes,

\footnotetext{
${ }_{1}^{1}$ Esta afirmación debe sin embargo tomarse con las reservas correspondientes, dada la falta de investigaciones existentes al respecto para la Banda Oriental durante la colonia. Algunos inventarios y testamentos del período colonial se refieren a grabados que se encontraban en posesión de distintas familias, pero sin brindar mayor información sobre sus procedencias. Aunque podamos suponer que buena parte fuese de origen europeo, como sucedió para toda la América hispana, no pueden descartarse las producciones regionales, de las misiones jesuíticas y de Buenos Aires. Igualmente estamos siempre frente a productos no realizados en Montevideo ni en el resto de la Banda Oriental. Ver como ejemplo AZAROLA GIL, Luis "Un testamento de la época colonial" en Revista Histórica, publicación del Museo Histórico Nacional, año LIX ( $2^{\mathrm{a}}$ época), tomo XXX, Nros. 88-90, Montevideo, Monteverde y Cia, 1960, específicamente la página 503.
} 
con el interés añadido de ser producciones locales, cuyo contenido versaba sobre asuntos de pública notoriedad y que afectaban directamente a la población. Por esta razón incidieron en la formación de corrientes de opinión, en momentos que las circunstancias políticas internas y regionales llevaron a la dirigencia de Montevideo a buscar apoyos populares e internacionales para su causa, también a través del uso de las imágenes. ${ }^{2}$ Del mismo modo el gobierno de Juan Manuel de Rosas, en Buenos Aires, llevó adelante una campaña de uso de las imágenes con marcado sentido político.

Dicha producción estuvo estrechamente ligada a técnicas de impresión/estampación y a técnicos europeos, que a su vez formaron a los primeros estampadores locales. El desarrollo de la prensa escrita 3 y de la edición de libros y folletos, iniciativas para las cuales se realizaron diversas láminas, también propició el interés de los dibujantes y editores, que tomaron como referencia publicaciones europeas, llegando incluso, cuando se daban las condiciones, a visitar sus imprentas para conocer los adelantos técnicos y las posibilidades de su aplicación local.

En el Uruguay, la producción de estampas sobre la que tratamos queda circunscripta a la capital, y conoce un importante desarrollo en el período del Sitio (1843-1851), cuando en las imágenes publicadas se destacaron contenidos políticos explícitos, incentivando un proceso que había comenzado algunos años atrás. Lo dicho no implica que estas imágenes no circularan por el interior, a partir de las rutas

\footnotetext{
${ }^{2}$ En este sentido es interesante el caso del gobierno del Cerrito. La documentación conservada prueba el interés en la adquisición de una imprenta con todos sus materiales y herramientas, útiles para la publicación del periódico El Defensor de la independencia americana. También en esa papelería se hace referencia a útiles para litografía, que no parecen haber hallado aplicación. El uso continuo de estampas y publicaciones ilustradas como arma política y como documento de actualidad fue un privilegio de Montevideo. Ver MAGARIÑOS DE MELLO, Mateo, El Gobierno del Cerrito, Montevideo, 1953, tomo II Poder Legislativo, p. 178 y ss.

3 Los estudios sobre la historia de la prensa oriental, sus contenidos y dimensiones se han desarrollado desde el siglo XIX. A modo de ejemplo ZINNY, Antonio, Historia de la prensa periódica de la República Oriental del Uruguay, 1807-1852, Buenos Aires, Imprenta y Librería de Mayo, 1883; ÁLVAREZ FERRETJANS, Daniel, Desde la Estrella del Sur a internet. Historia de la prensa en el Uruguay, Montevideo, Editorial Fin de Siglo, 2008. Sobre los contenidos y dimensiones ideológicas de la prensa, citamos a modo de ejemplo entre otros artículos del mismo investigador, GONZALEZ DEMURO, Wilson, "El sol de las Provincias Unidas, un comentario sobre el periodismo, la revolución y la difusión de ideas en Montevideo a fines de la época colonial", en CLAHR, Colonial Latin América historial review, vol. 13, No 1, Albuquerque, 2004 (2006), pp. 53-87; "Un juez severo al que temen aún los gobiernos más despóticos. El concepto de opinión pública en la prensa oriental durante la revolución (1810-1820)" en Humanidades. Revista de la Universidad de Montevideo, No XII, Montevideo, 2013, pp. 97-124; "La historiografía de la prensa periódica en Uruguay (1880-2010) Perfiles, avances y asuntos pendientes", en Chasqui, Revista Latinoamericana de Comunicación. Disponible en: $<$ www.revistachasqui.org/index.php/chasqui/article/view/434/433>.
} 
fluviales y de los caminos rurales, pulperías y poblados, pero a la fecha no es posible brindar cifras concretas o datos más precisos al respecto. 4

Las imágenes eran fácilmente accesibles para los interesados en las librerías y en las imprentas. Reconocemos la receptividad que tenían en la sociedad dado que fueron reiteradamente anunciadas en la prensa como estrategia de comercialización y difusión, buscando despertar el interés de los potenciales compradores.

La mayoría de los datos, acuarelas y estampas que se citan e insertan en este artículo fueron relevados en un trabajo de investigación que desde hace varios años he venido desarrollando sobre arte nacional del siglo XIX. En esta oportunidad se sintetizan algunos aspectos ya tratados acerca de la generación de estampas y su significación, y se avanza especialmente en el trabajo de un dibujante y acuarelista como Juan Manuel Besnes e Irigoyen y su relación con la realización de estampas e ilustraciones para libros y periódicos.

\section{Nuevas técnicas y nuevos medios}

A lo largo del siglo XIX coexistieron en Montevideo distintos sistemas de impresión y estampación. Esta circunstancia requiere unas breves puntualizaciones, ya que sin su difusión habría sido imposible la publicación de materiales ilustrados, dado que ninguna de estas técnicas fue de origen local. En este sentido, el libre comercio y el afianzamiento de los lazos con Europa, así como la inmigración de personal calificado, fueron factores determinantes para toda la región platense. El desarrollo tecnológico y comercial, la progresiva presencia de técnicos, como José Gielis o Luciano Mège5, y la labor que cumplieron enseñando la técnica a residentes

\footnotetext{
4 Un indicio acerca de la difusión de estas estampas fuera de las ciudades capitales lo brindan los redactores de El Grito Argentino (1839), una de las primeras publicaciones ilustradas anti rosistas impresa en Montevideo: "Los buenos campesinos no le temen, no; así es que se nos pide El Grito de muchas partes de la campaña de Buenos Aires; y nos consta del modo más positivo que cuando llegan a agarrar uno, lo leen en rueda, en los ranchos, pulperías, carreras..." El Grito Argentino, No 16, Montevideo, Imprenta de la Caridad, 21 de abril de 1839. Si bien el interés de los publicistas era exportar los números ilegalmente a la campaña bonaerense, la relación medio rural/medio urbano era similar a la que se daba en el Estado Oriental.

Horacio Arredondo, José María Fernández Saldaña y otros investigadores uruguayos que se dedicaron a acrecentar las colecciones museográficas, refirieron haber hallado láminas de alto valor histórico, costumbrista y artístico en pulperías perdidas de la campaña, lo cual, con las consideraciones del caso, podría ser un indicio relativo a esta circulación.

5 José Gielis (Courtrai, Bélgica, hacia 1809-Montevideo, 1848) llegó al Uruguay a principios de la década de 1830, trabajando como litógrafo, siendo propietario de uno de los más importantes talleres de la primera mitad del siglo XIX. Además de las estampas que produjo, de las cuales se conservan algunas,
} 
locales -casos de Juan Manuel Besnes e Irigoyen y Ramón Irigoyen-, hizo posible el incremento de la producción de estampas a medida que avanzó el siglo XIX. ${ }^{6}$

En el Río de la Plata, durante el período colonial, además de los impresos procedentes de España y sus territorios europeos7, hubo un relativo desarrollo de la imprenta en las Misiones jesuíticas, y posteriormente en Córdoba y en Buenos Aires, capital virreinal. ${ }^{8}$ Montevideo, fundada en la primera mitad del siglo XVIII recibió materiales de estas procedencias: la imprenta porteña de los Niños Expósitos imprimió bandos y formularios que eran remitidos por la administración colonial. Recién en 1807 llegó la imprenta con las tropas invasoras inglesas, y a partir de entonces, en un proceso conocido y que no podemos abarcar aquí, se establecieron sucesivas imprentas, de más larga o breve actividad y que muchas veces utilizaron los mismos tipos y prensas, que pasaban de mano, complementándolas con la adquisición de

y sobre las que nos informa reiteradas veces la prensa, el listado del remate de los materiales y herramientas que tenía en su taller, realizado tras su fallecimiento, permite hacerse una idea de su relevancia. Ver Comercio del Plata, Montevideo, 10 de marzo de 1849.

Luciano Mège (Bayona, Francia, 1808-s/d). Litógrafo establecido en Montevideo hacia 1842, mantuvo sociedad con otros estampadores, como Lebas, y en la segunda mitad del siglo, con Willems. Fue autor de los primeros sellos nacionales, denominados "diligencias", incursionó en el grabado de metales, en la acuñación de monedas y en la impresión de libros.

Fue habitual que estos técnicos cultivaran diversas actividades simultáneamente, dibujo y pintura, litografía, caligrafía, grabado en metales y diseño, y también se dedicaban a la enseñanza. Su polifacética ilustración resulta interesante, pero es un tema en el que todavía debe profundizarse.

${ }^{6}$ A partir de 1851 se establecieron en Montevideo las grandes casas litográficas, de las cuales han quedado en los reservorios buen número de estampas, muchas de gran tamaño y en colores (cromolitografías). Estampas con estas características no eran frecuentes en el período que estamos tratando -aunque hay excepciones-, que constituye la primera etapa de la estampación de láminas en el país. Alfredo Godel, José Adolfo Héquet, Goffredo Sommavilla, entre otros, tuvieron a su disposición adelantos técnicos y un mayor número de publicaciones para ilustrar, entre otras Ilustración uruguaya.

7 Desde el siglo XVI España envió a las colonias obras de carácter religioso, muchas ilustradas con grabados. Estas estampas eran utilizadas por los artistas indígenas y criollos, que las copiaban para abastecer de pinturas a las iglesias que el afán evangelizador levantaba de continuo, quedando garantizada la fidelidad a los dogmas de la iglesia. Impresores y grabadores, como Plantin-Moretus, Wierix o Volswert eran sus productores. Ver GUTIERREZ, Ramón (coord.), Pintura, escultura y artes útiles en Iberoamérica, 1500-1825, Madrid, Arte Cátedra, 1995. Esta costumbre de emplear ilustraciones como modelo no fue ajena incluso a los grandes artistas europeos, y fue asimilada también por los que actuaron en nuestro país.

8 Distintos estudios abordaron este tema. Remitimos a algunos títulos que, pese a su antigüedad, contienen un importante caudal informativo: UGARTECHE, Félix de, La imprenta argentina. Sus orígenes y desarrollo, Buenos Aires, Talleres Gráficos R. Canals, 1929; ESTRADA, Dardo, Historia y bibliografía de la imprenta en Montevideo 1810-1865, Montevideo, Librería Cervantes, 1912; FERNÁNDEZ y MEDINA, Benjamín, La imprenta y la prensa en Uruguay desde 1807 á 1900, Montevideo, Imprenta de Dornaleche y Reyes, 1900; FURLONG, Guillermo, Historia y bibliografía de las primeras imprentas rioplatenses 1700-1850, (3 tomos), Buenos Aires, Editorial Guarania, 1953; HERAS, Carlos, Orígenes de la imprenta de Niños Expósitos con una introducción sobre «Los primeros trabajos de la imprenta de Niños Expósitos», La Plata, Publicaciones del Archivo Histórico de la Provincia de Buenos Aires, Documentos del Archivo, Tomo x, Taller de Impresiones Oficiales, 1943. DUARTE, Jacinto, Dos siglos de publicidad en la historia del Uruguay, Montevideo, 1952. 
nuevos elementos. La culminación se alcanzó con el establecimiento de la "Imprenta de la Caridad", cuyos impresos son considerados los de mejor calidad a partir de los años 1820.9

La libertad de imprenta establecida por las autoridades luso brasileñas, y posteriormente por la Constitución de 1830, facilitó este proceso y familiarizó a la población local con la circulación de ideas de diversas orientaciones filosóficas, dentro del marco legal vigente, cuando durante la dominación española la vigilancia de las autoridades censuraba aquellos materiales que supusieran un cuestionamiento a la monarquía. ${ }^{10}$

Sin embargo, en los impresos locales conservados, anteriores a 1830, las imágenes escasean, reduciéndose en general a guardas decorativas o emblemas, no encontrándose imágenes complejas en su planteamiento y significación, aunque muchas veces resulten claramente simbólicas. ${ }^{11}$ Tanto The Southern Star como la Gazeta de Montevideo ${ }^{12}$ llevaban como única decoración en sus encabezados el escudo inglés y el de Montevideo, respectivamente.

Esta novedosa producción introdujo a los lectores en una nueva cultura visual, en la cual la diagramación, los textos compartimentados e informados por ilustraciones, o bien la posibilidad de leer los artículos y luego contemplar estampas

9 FURLONG, Guillermo, La Imprenta de la Caridad (1822-1855), Montevideo, El Siglo Ilustrado, 1932; DUARTE, Jacinto, ob. cit.

10 Sin embargo, durante el período colonial, el puerto de Montevideo fue vía de acceso para materiales impresos contrabandeados, que eran portadores de nuevas ideas y cuestionaban en algunos casos la figura del monarca. Se conserva el expediente sobre la incautación de unas láminas que mostraban la ejecución del rey francés Luis XVI, tema que resultaba alarmante por lo que implicaba como desafío a la figura real. BERETTA, Ernesto, «Las autoridades en alerta. Una aproximación a la imagen en el Río de la Plata y a su vertiente anti monárquica», en Simposio A 200 años de la Junta de Gobierno en Montevideo: soberanía y pacto colonial ante la crisis de la monarquía española, Montevideo, 2008, Archivo y Museo Histórico Municipal, Cabildo de Montevideo. Inédita.

${ }^{11}$ En los impresos vemos viñetas diversas, representando elementos de la cultura material, relacionados con el contenido de los anuncios, o con el sentido de las publicaciones. El más completo inventario de materiales decorativos se encuentra en Muestra de caracteres de letras, geroglíficos (sic) y guarniciones que existen en la Imprenta de la Caridad, Montevideo, Imprenta de la Caridad, 1838. Resulta curioso que algunos tipos reflejaron elementos esencialmente locales, como las carretas de campaña, planteando el interrogante sobre su producción en plaza o su encargo al exterior. Muchos tipos provenían de los Estados Unidos de Norteamérica. Ver GRÜNWALDT RAMASSO, Jorge, Vida, industria y comercio en el antiguo Montevideo 1830-1852, Montevideo, Barreiro y Ramos, 1970.

12 The Southern Star / La estrella del Sur, Montevideo 1807, reproducción facsimilar por el Instituto Histórico y Geográfico del Uruguay, Montevideo, Barreiro y Ramos, 1942.

Gazeta de Montevideo, Colección Biblioteca de impresos raros americanos, volumen 1 (1810 octubrediciembre), volumen 2 (1811 enero-junio), Montevideo, Universidad de la República, Facultad de Humanidades y Ciencias, Instituto de Investigaciones Históricas, 1948 y 1954. 
sueltas sobre ellos, o a la inversa, proporcionaron un mayor caudal informativo y una nueva manera de vincularse a los episodios de actualidad. Los insumos visuales se convirtieron en un recurso original, utilizado progresivamente, a la vez que, por sus características de materiales portables, ingresaron hasta los hogares entre las hojas de libros, periódicos y diarios. ${ }^{13}$

Inicialmente, las imágenes se introdujeron en los títulos y encabezados como la escena que aparece en el periódico La diablada o el robo de la Bolsa (1832). ${ }^{14}$ Pero son los periódicos que se publicaron durante el período 1839-1851 los primeros en hacer proliferar en forma continua las imágenes en las páginas de sus números ${ }^{15}$, coexistiendo además con las estampas sueltas que publicaban los talleres litográficos locales.

Las técnicas aplicadas en la estampación de imágenes para las publicaciones ilustradas durante el siglo XIX fueron básicamente tres: el grabado sobre metal (aguafuerte), el grabado en madera (xilografía) y el dibujo con lápices grasos sobre piedra (litografía). En el caso montevideano, siguiendo la situación europea, la litografía fue el método más utilizado, seguido a distancia por la xilografía. Un factor

13 Referimos algunos estudios sobre percepción y cultura visual: LOWE, Donald, Historia de la percepción burguesa, México, FCE, 1986. Para el Río de la Plata, AMIGO, Roberto, "Imágenes sitiadas. Tradiciones visuales y política en el Río de la Plata 1830-1870, en MERAo7, Memorias del encuentro regional de arte, tomo 2, Montevideo, 2009, pp. 59-75. Para un análisis sobre las imágenes en medios de prensa en el Río de la Plata en la segunda mitad del siglo XIX, ver en la misma serie, MALOSETTI COSTA, Laura, "Exilios, revistas y cuadros en el origen de un sistema artístico moderno en la región", en MERAO7, Memorias del encuentro regional de arte, tomo 1, Montevideo, 2009, pp. 84-97.

${ }_{14}$ La diablada o el robo de la bolsa, Montevideo, Imprenta de la Libertad, No 1, 6 de marzo de 1832 a Nro. 5, 21 de marzo de 1832.

${ }_{15}$ Nos referimos a El Grito Argentino, Montevideo, Imprenta de La Caridad, Nro. 1, 25 de febrero de 1839 a No 33, 30 de junio de 1839; Muera Rosas! Periódico semanal. Patria! Libertad! Constitución!, Montevideo, Imprenta Constitucional, No 1, 23 de diciembre de 1841 a No 13, 9 de abril de 1842; El Tambor de la Línea (1843), sin datos. La colección que se conserva en la Biblioteca Nacional, en Montevideo, contiene tres números, uno sin indicación y los números dos y tres. De acuerdo a ZINNY, Antonio, ob. cit, cuenta también con un prospecto; El Telégrafo de la Línea. Semanario de guerra y del ejército. Unión y Libertad, Montevideo, Imprenta de la Caridad, No 1, 24 de setiembre de 1844 a No 24, 18 de mayo de 1845, y La Defensa, Montevideo, Imprenta Francesa, No 1, 2 de agosto de 1851 a No 51, 3 de octubre de 1851 .

Estos periódicos anti rosistas han sido analizados recientemente por investigadores argentinos: FERRO, Gabo, Barbarie y civilización, sangre, monstruos y vampiros durante el segundo gobierno de Rosas, Buenos Aires, Editorial Marea, Colección Pasado Imperfecto, 2008; ROMÁN, Claudia, «Caricatura y política en El Grito Argentino (1839) y iMuera Rosas! (1841-1842)», en Gabriela, BATTICUORE, Klaus GALLO y Jorge MYERS (comp.), Resonancias románticas, Ensayos sobre historia de la cultura argentina (1820-189o), Buenos Aires, Eudeba, 2005, pp.49-69; FÜKELMAN, María Cristina, «La construcción de un tipo iconográfico: la figura de Juan Manuel de Rosas en la prensa opositora: caricatura y sátira en la prensa antirrosista», en Anuario del Instituto de Historia Argentina, año VI, Universidad de La Plata, Facultad de Humanidades y Ciencias de la Educación, La Plata, 2006, pp. 97124. 
que resultó esencial en el éxito de la técnica fue que, en caso de reproducir como noticia acontecimientos de actualidad, resultaba un método rápido, que permitía publicar las imágenes inmediatamente producidos los sucesos narrados. Se caracteriza además por ser un método relativamente sencillo de poner en práctica. ${ }^{16}$

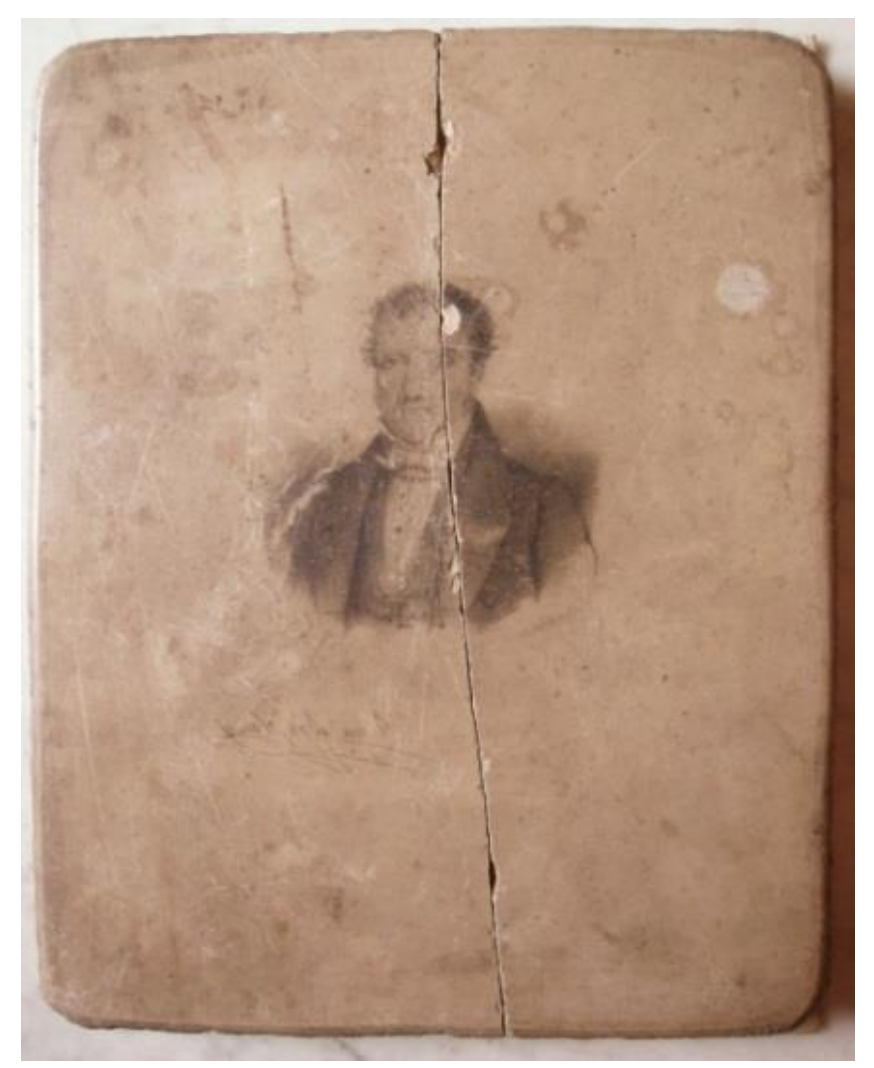

Foto 1: Piedra litográfica con retrato de Aimé Bonpland, Montevideo, Museo Histórico Nacional (en adelante MHN), carpeta Nro. 2681.

\section{Las vinculaciones europeas}

La producción local de estampas se vio propiciada por el desarrollo de los contactos comerciales y culturales con Europa en el marco del liberalismo, y por la voluntad de la élite urbana de alcanzar mayor desarrollo cultural y artístico, incluyendo herramientas publicitarias modernas. En el proceso de afincamiento en la ciudad de distintas técnicas y en la información circulante sobre diversas materias, el arribo de bibliografía, herramientas y materiales resultó tan importante como la presencia de técnicos europeos. La revisión de las estadísticas de aduanas permite verificar el arribo

\footnotetext{
16 Pese a resultar algo confusos en su redacción, los apuntes de Besnes e Irigoyen acerca de sus primeras incursiones con Gielis en la técnica litográfica, en 1836, muestran lo sencillo del método. Ver BESNES E IRIGOYEN, Juan Manuel «Álbum», p. 42 y ss, en Obra de Besnes e Irigoyen en Biblioteca Nacional, Montevideo, Biblioteca Nacional, 2004 (edición en dos CD). Disponible en: http://bibliotecadigital.bibna.gub.uy:8080/jspui/handle/123456789/19670
} 
periódico de piedras litográficas, lápices, tintas, papeles y prensas. Si bien se informaba que podían utilizarse varios tipos de piedra, se reconocía que la procedente de las canteras germánicas, la llamada piedra Kelheim ${ }^{17}$, era la más apropiada, de allí su importación y el mayor precio de las publicaciones ilustradas. ${ }^{18}$

El circuito terrestre y marítimo que permitió la difusión por el hemisferio occidental de la litografía comenzó hacia 1798 en Baviera, al ser descubierta la técnica por Alois Senefelder, irradiando en los años siguientes por las naciones de Europa. Llegó a los Estados Unidos de Norteamérica hacia 1819, y al Río de la Plata, a Buenos Aires en la década de $1820^{19}$ y a Montevideo en la de 1830 . Pero estos tres destinos americanos no están conectados entre sí en forma transitiva, es decir, la litografía no llegó a Montevideo desde ellos, sino directamente desde Europa, a partir del traslado de litógrafos que se afincaron temporal o permanentemente en la ciudad. ${ }^{20}$

La llegada de publicaciones europeas fue continua a lo largo del siglo XIX y las mismas fueron las fuentes informativas $\mathrm{y}$, muchas veces, de inspiración para los

\footnotetext{
17 Para la técnica litográfica ver EICHENBERG, Fritz, Lithography and Silkscreen, art and technique, Nueva York, Harry N. Abrams, 1978 y VICARY, Richard, Manual de Litografía, Madrid, Hermann Blume, 1986.

${ }^{18}$ En Montevideo se hizo costumbre que las imprentas ofrecieran los mismos títulos en dos ediciones, una ilustrada y otra sin ilustrar, con precios distintos. Esta situación se verifica en los ejemplares conservados. Un aviso en el diario El Nacional, refiriéndose a un poema de José Rivera Indarte publicado por la imprenta del mismo diario consigna: "con láminas un peso el ejemplar, sin ellas cuatro reales.” BERETTA GARCIA, Ernesto, Imágenes para todos.La producción litográfica, la difusión de la estampa y sus vertientes temáticas en Montevideo durante el siglo XIX. Primera parte, de la constitución del Estado Oriental al fin de la Guerra Grande, Montevideo, Universidad de la RepúblicaCSIC, 2015.

19 El relato del francés Jean Baptiste Douville, uno de los pioneros de la litografía porteña, es ilustrativo de la conjunción de factores que se daba en las ciudades portuarias, en este caso Buenos Aires:

"Un día, hallé en los almacenes de un comerciante inglés conocido, una prensa litográfica con todos sus accesorios, y concebí inmediatamente la idea de litografiar los retratos de los grandes hombres de la República Argentina. Yo jamás había ejercido el arte de la litografía, pero había visto trabajar a los obreros, dibujaba relativamente bien, y además poseía algunas nociones de química, por lo que esperaba tener éxito al fabricar los lápices grasos necesarios. Una feliz oportunidad vino en mi ayuda: yo conocía a M. Lainé, francés de nacimiento y buen pintor, que se había establecido en Buenos Aires hacía unos años. Le hablé de mi proyecto, y le pareció ventajoso llevarlo adelante. Inmediatamente formamos una sociedad."

DOUVILLE, Jean Baptiste, 30 mois de ma vie, ou quinze mois avant et quinze mois après mon Voyage au Congo, accompagné de pièces justificatives, de détails nouveaux et curieux sur les mœurs et les usages des habitans du Brésil et de Buenos-Ayres, et d'une description de la colonie Patagonia, París, 1833, pp. 101-103 para la totalidad del fragmento parcialmente citado aquí.

${ }^{20}$ Resulta interesante señalar que el litógrafo Bacle, establecido en Buenos Aires, atento a la ausencia de casas de litografía en Montevideo a fines de la década de 1820, ofrecía realizar en su establecimiento bonaerense los trabajos y enviarlos a Montevideo. Contaba para esto con un apoderado en la ciudad. De este modo se estampó el "Plano topográfico del pueblo de Montevideo", en base al dibujo de dicho socio, Adrián Henniquen Mynssen. Ver BERETTA, Ernesto, Imágenes para todos...ob. cit.
} 
dibujantes y litógrafos. Los listados publicados en la prensa local, y los catálogos de las librerías, como el de la librería de Jaime Hernández², nos permiten conocer la cantidad de materiales importados, la diversidad temática y, a partir de la comparación con las producciones locales, la clara inspiración en ellos de algunos trabajos de artistas radicados en Montevideo. La formación de los primeros cenáculos de carácter intelectual, como el que funcionó en la librería de Hernández, fueron espacios de debate, intercambio de ideas y aproximación a las novedades editoriales, artísticas y técnicas que llegaban a puerto. ${ }^{22}$

Juan Manuel Besnes e Irigoyen y José Gielis tomaron imágenes de la revista española El Artista ${ }^{23}$, copiándolas y mejorándolas para publicaciones montevideanas. Gielis copió la estampa del monumento a Miguel de Cervantes, del escultor Antonio Sola, erigido en Madrid, para el folleto A Miguel de Cervantes Saavedra Príncipe de los Ingenios Españoles. ${ }^{24} \mathrm{El}$ único ejemplar suelto que parece haberse conservado se encuentra pegado en uno de los álbumes de Besnes e Irigoyen. ${ }^{25}$ En caso de no haber contado con este modelo, es posible que hubieran sido accesibles a Gielis grabados con el retrato del escritor, o ediciones de sus obas que incorporasen su retrato en la portada, costumbre también adoptada en Montevideo por los impresores, siguiendo las pautas europeas. ${ }^{26}$ Besnes tomó de El artista un dibujo de Faramundo Blanchard, "El

${ }^{21}$ Catálogo de los libros ecsistentes (sic) en la librería de Jaime Hernández, Diciembre 4 de 1837, Calle de s. Pedro junto a la sala de comercio, no 1, Montevideo, Imprenta de la Caridad, 1838.

${ }_{22}$ De acuerdo a Antonio Pereira, en la librería se reunían los poetas e historiadores uruguayos y los exiliados de Buenos Aires. PEREIRA, Antonio, Nuevas cosas de antaño, Montevideo, El Siglo Ilustrado, 1898. Citado en SPERONI VENER, Julio, «Noticias bibliográficas. Un folleto raro de Ascasubi: la edición original del Paulino Lucero», en Revista Histórica, Publicación del Museo Histórico Nacional, Año LIV, $2^{\mathrm{a}}$ época, tomo XXX, Nros. 88-90, pp. 510-543, Montevideo, Monteverde y Cía., 1960, p. 517. También se exhibieron allí documentos de importancia pública, algunos de los primeros daguerrotipos del abate Comte y distintos artistas daban la librería como referencia para los cursos que brindaban. BERETTA, Ernesto, Los inicios de la europeización artística en Montevideo, entre la Independencia y el Sitio (1830-1843), proyecto modalidad Iniciación a la investigación, Universidad de la República-Comisión Sectorial de Investigación Científica, 2005-2006 (inédito).

23 MADRAZO, Federico y OCHOA, Eugenio (ed), El artista, Madrid, Imprenta de I. Sancha, 1835-1836. ${ }^{24}$ A Miguel de Cervantes Saavedra Príncipe de los Ingenios Españoles, Montevideo, Imprenta Oriental, 1838.

${ }^{25}$ BESNES E IRIGOYEN, Juan Manuel, álbum "Prontuario de Paisages" (sic), en Obra de Besnes e Irigoyen en Biblioteca Nacional, ob. cit., p. 47a.

${ }^{26}$ Un ejemplo es el libro Poesías de D. Adolfo Berro, Montevideo, Imprenta del Nacional, 1842, que incluye el retrato del poeta, realizado por Antonio Somellera, militar y dibujante opositor de Rosas, refugiado en Montevideo por sus implicancias en la distribución de materiales impresos clandestinos. 
Trovador", que se le pidió para ilustración de la obra del mismo título publicada por la Biblioteca Dramática. ${ }^{27}$

Resulta interesante el origen de muchos litógrafos, tanto para Montevideo como para Buenos Aires: Francia o los territorios que estuvieron bajo su influencia durante la expansión napoleónica. Esta circunstancia podría relacionarse con el interés despertado por la técnica en Francia y las facilidades que se otorgó al establecimiento de talleres. José Gielis era natural de Bélgica, Luciano Mège de Francia y César Bacle de Suiza. Los tres desarrollaron una importante actividad como estampadores, los dos primeros en Montevideo y el tercero en Buenos Aires. ${ }^{28}$

También los editores de diarios, periódicos y libros estuvieron pendientes de las novedades. Es ilustrativo el caso del impresor y librero Jaime Hernández, ya que en 1837 el litógrafo Gielis trasladó su taller litográfico a dicha imprenta. Este hecho, que a primera vista no llamaría la atención, resulta revelador del interés del impresor por contar con técnicos calificados, a los cuales recurrir para la ilustración de sus publicaciones, y poder ofrecer así materiales adecuados a la nueva cultura visual que se estaba definiendo. Hernández editó varias obras con imágenes en sus páginas, como las de Hilario Ascasubi, Paulino Lucero... y La encuetada29, con ilustraciones litográficas realizadas en Montevideo por la sociedad Mège-Lebas. Paulino Lucero... incluyó la reproducción de una litografía del argentino Carlos Morel ${ }^{30}$, concretamente

\footnotetext{
${ }_{27}$ Biblioteca Dramática, Selecta y escojida [sic] de las mejores piezas del teatro moderno. La Marcela y El Trovador, Autores Sr. Bretón de los Herreros y D. A. G. Gutiérrez, Montevideo, Imprenta de la Caridad, 1837. Besnes utilizó en forma recurrente materiales bibliográficos importados para la realización de sus propias obras. Ver BERETTA, ERNESTO, Mucho más que buena letra. El arte caligráfico en Montevideo durante el siglo XIX, Universidad de la República-CSIC, Editorial Fin de Siglo, 2011.

En el proceso de investigación sobre la obra de Besnes hemos hallado también la copia de figuras de decoración grutesca diseñadas por Rafael Sanzio, seguramente tomadas de álbumes o libros sobre bellas artes, y de máximas morales extraídas del libro del MARQUES DE CARACCIOLO, Última despedida de la Mariscala a sus hijos: compuesta en francés por el Marqués Caracciolo, \&c. y traducida en castellano por Don Francisco Mariano Nipho, Barcelona, Impresor Juan Francisco Piferrer, 1823.

${ }_{28}$ Muchos técnicos emigraron al Plata en las décadas de 1820 y 1830 debido al resurgimiento de los regímenes absolutistas y a la política represiva que desplegaron contra los partidarios del liberalismo y de los movimientos revolucionarios del momento. Las nuevas naciones americanas aparecieron en el imaginario liberal como los espacios donde construir nuevas sociedades, donde las monarquías "corruptas" habían sido derrotadas. Se combinaba el exilio político y la necesidad de trabajo con el aporte de conocimientos específicos para el desarrollo de estas nuevas naciones.

29 ASCASUBI, Hilario, Paulino Lucero ó dos gauchos en Entre Ríos, Montevideo, Imprenta HispanoAmericana, 1846 y La encuetada ó los gauchos y la intervención en el Río de la Plata, Montevideo, 1848.

30 Carlos Morel (Buenos Aires, 1813-1894) pintor argentino, a partir de cuyos trabajos se estampó el álbum titulado "Usos y costumbres del Río de la Plata" (1844). Roberto Amigo abordó la obra de Morel,
} 
la titulada "El cielito (danza)", lo cual nos permite confirmar la existencia de contactos y un conocimiento de la producción litográfica regional. De hecho, la misma librería de Hernández, anunciaba la venta de cuadernos con estampas de las casas litográficas porteñas de Bacle y de Ibarra.

En oportunidad de viajes a Europa, los editores y publicistas locales aprovechaban la ocasión para visitar bibliotecas, editoriales e imprentas, con el fin de conocer los últimos adelantos técnicos y las nuevas estrategias desplegadas para captar lectores. Florencio Varela, enviado en misión diplomática por el gobierno de la Defensa, visitó las imprentas del Times y de The Illustrated London News:

“...fui a visitar las oficinas y prensas del Times, en la Ciudad, para lo que obtuve una introducción. Aunque conocía, tiempo hace por dibujos, planos y descripciones, el sistema de la prensa del Times, y aunque había visto una trabajando, en el Banco, no he podido dejar de mirar con sumo interés las que emplea actualmente aquel periódico, el más derramado de todos. Como no me sería fácil hacer aquí una descripción de esas máquinas, la refiero a las que existen impresas, y a la que acompaña la lámina adjunta, que representa una máquina de la misma clase que la del Times. Este emplea tres prensas, y según me aseguró la persona encargada de mostrármelas, tiran a razón de 72 ejemplares por minuto, lo que da uno un tercio por segundo, y / 4.320 por hora. Supongo que la prensa de la adjunta lámina, que es la del Illustrated London News, trabajará en igual proporción, y que las 2.000 impresiones perfectas que se dice que hace por hora, son impresiones por los dos lados del pliego, lo que da 4.000 de un lado, como el Times." ${ }_{1}$

Considerando que poco después, en 1845, incursionó en la publicación de un diario como el Comercio del Plata32, comprendemos su interés en estas cuestiones.

\footnotetext{
incluyendo este álbum. Ver AMIGO, Roberto; "Carlos Morel. El costumbrismo federal”. En Caiana. Revista de Historia del Arte y Cultura Visual del Centro Argentino de Investigadores de Arte (CAIA), $\mathrm{N}^{\circ} \quad 3, \quad$ Año $2013 . \quad$ http://caiana.caia.org.ar/template/caiana.p hp?pag=articles/article_2.php\&obj=115\&vo l=3

${ }_{31}^{1}$ Varela, Florencio, "El diario de viaje inédito de Florencio Varela por Inglaterra y Francia (1843-1844)" en Revista Histórica publicación del Museo Histórico Nacional, año LXVIII y LXIX, $2^{\mathrm{a}}$ época, tomo XLV y XLVI, Nros. 133-135 y 136-138, Montevideo, 1974, 1975, pp. 195-379 y 245-406.

${ }^{2}$ Diario Comercio del Plata, Montevideo, Buenos Aires, Nro. 1, 1 de octubre de 1845 a Nro. 3735, 31 de mayo de 1860.
} 


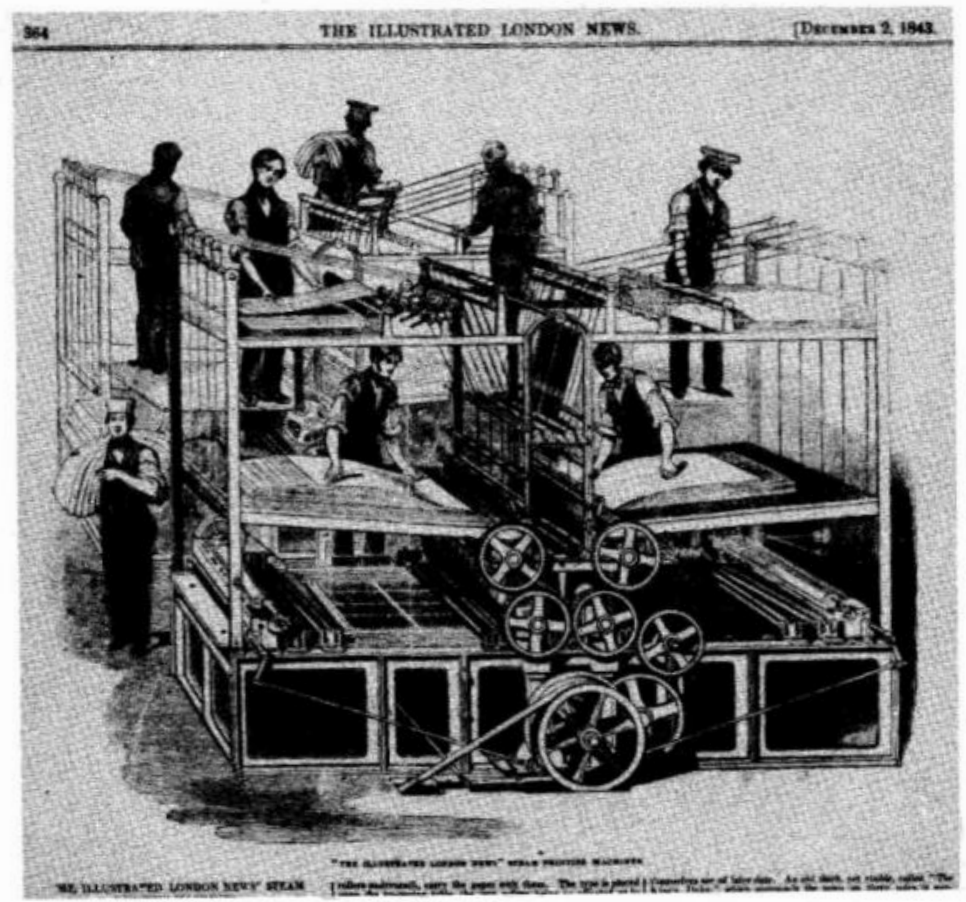

Foto 2: Grabado de la imprenta de The Illustrated London News, conservado por Florencio Varela en su "Diario de viaje por Inglaterra y Francia". Tomado de Revista Histórica, ob. cit., lámina 9.

La presencia de escuadras inglesas y francesas, así como de misiones diplomáticas de estas naciones durante la Guerra Grande, propició el contacto de la elite de Montevideo con artistas que participaron de las mismas, o con militares y diplomáticos que tenían nociones de dibujo y relaciones con imprentas europeas, y que se dedicaron a documentar los tipos humanos, paisajes y acontecimientos platenses. Dos casos representativos son el francés Adolphe D’Hastrel y el inglés William Gore Ouseley.33 Ambos desarrollaron una práctica frecuente en la época: tomar apuntes y realizar acuarelas para su posterior pasaje a litografía de las vistas y escenas y su inserción en álbumes o libros de viaje. Estas relaciones se mantuvieron más allá del retorno a Europa de estos artistas, una vez finalizadas las misiones en las que participaron. Cuando Florencio Varela visitó París retomó contacto con D’ Hastrel, a quien había conocido en Montevideo.34 Es interesante considerar hasta qué punto nuestros dibujantes se pueden haber inspirado en las formas de trabajo que aquellos

\footnotetext{
33 Adolphe D’ Hastrel (Francia, 1804-1875) y William Gore Ouseley (Londres, 1797-1866) son dos de los más reconocidos documentalistas en imágenes para el Río de la Plata. A partir de sus acuarelas se estamparon en Europa álbumes con sus vistas, escenas y tipos humanos regionales. Citamos como ejemplo "Vista de Montevideo desde el Cementerio", acuarela de Gore Ouseley comentada en Description of views in South América from orginal drawings made in Brazil, the River Plate, the Paraná, lithographed by Needham, London, Thomas Mc Lean, 1852.
}

34 VARELA, Florencio, ob. cit. 
desplegaban, y en los consejos que podían brindarles. Por los apuntes de Besnes, sabemos que conoció a Gore Ouseley, a quien obsequió uno de sus trabajos caligráficos. 35

Esta relación a dos puntas entre Europa y El Plata incluía los viajes en uno y otro sentido, la recepción local de materiales, herramientas y técnicos europeos, la llegada de imágenes sobre asuntos europeos a Montevideo, y la producción de imágenes sobre asuntos platenses en Francia o Inglaterra. Pero la investigación sobre estos aspectos esbozados todavía debe profundizarse.

Esta circulación de imágenes puede ampliarse a una vía de difusión más atractiva e impactante visualmente como eran los gabinetes ópticos, dioramas y cosmoramas. ${ }^{36} \mathrm{La}$ apertura de gabinetes ópticos al estilo de los europeos es otro síntoma de la irrupción de nuevas modalidades de carácter visual para acercarse a los acontecimientos y a las noticias, al conocimiento del mundo. Sin embargo debemos establecer una diferencia entre ellos, ya que en el primer caso se trata de espectáculos que esbozarían un público masivo. En estos cosmoramas se exhibían vistas universales y locales. Es interesante citar el ejemplo del "Cosmorama Español" que presentaba en un mismo programa una vista histórica de la batalla de las pirámides (1798), ganada por Napoleón Bonaparte y una de la batalla de Yucutujá, ganada por Fructuoso Rivera

35 Referencia dada por Irigoyen Artetxe, Marcelo, "Biografía de Besnes e Irigoyen" en Obra de Besnes $e$ Irigoyen en Biblioteca Nacional, ob. cit.

${ }^{36}$ En los gabinetes ópticos de Montevideo se exhibían estampas y litografías sobre asuntos de actualidad, combinando las láminas importadas con las producidas localmente.

Dioramas y cosmoramas, tal como eran entendidos en Montevideo, constituyen un antecedente muy incipiente de la cinematografía. Su fuente se encuentra en las pinturas con efectos lumínicos por transparencia, llevadas adelante en Europa por los artistas como curiosidad efectista para sus clientes aristocráticos. Una tela, pintada por ambos lados, pero sin saturarla de pintura, es decir permitiendo el pasaje de luz a través de ella, iluminándola por el frente o por detrás, ofrecía alternativamente una vista diurna y una nocturna, o la combinación de una vista exterior y una interior. No se conservan muchos ejemplos de estas creaciones, pero puede citarse el trabajo realizado por el pintor romántico alemán Caspar David Friedrich para el príncipe heredero de Rusia, Alejandro, en 1830. Ver BERETTA, Ernesto, «Antes del daguerrotipo: gabinetes ópticos, cosmoramas, máquinas para sacar vistas y experimentaciones con los efectos de luz en Montevideo durante el siglo XIX», en Artículos de investigación sobre fotografía 2008, Montevideo, CMDF, 2009, pp.9-39.

Esta técnica era conocida parcialmente en Montevideo y Buenos Aires en la denominada "pintura de transparentes". Consistía en telas tensadas sobre bastidores sobre las cuales se pintaban leyendas conmemorativas o de carácter republicano, máximas morales o bien figuras alegóricas. Se colocaban en las fachadas de los edificios, sobre las ventanas, y se iluminaban por detrás con faroles de colores. Contamos con las descripciones de varios de ellos, así como la transcripción de sus leyendas, pero no se han conservado ejemplares de los mismos, que formaban parte de las decoraciones efímeras para las festividades cívicas y religiosas, y que eran desechados finalizados los festejos. 
un año antes de la exhibición, en 1837.37 No pueden ignorarse las implicancias simbólicas de la asociación entre las dos batallas y los dos personajes.

\section{Estampas de actualidad}

Juan Manuel Besnes e Irigoyen y Ramón Irigoyen ${ }^{8}$ constituyen un ejemplo significativo de esta nueva categoría de artistas documentalistas, cuyos dibujos y acuarelas se tradujeron en estampas e ilustraciones para diversas publicaciones. Ambos pueden considerarse pioneros en lo referente a la introducción de los montevideanos en la nueva cultura visual, a través de una amplia variedad temática. De acuerdo a los datos disponibles, también Gielis habría tomado apuntes sobre diversos acontecimientos como testigo presencial para luego realizar las estampaciones correspondientes. 39

A las estampas publicadas, debe sumarse un conjunto de pruebas litográficas, y noticias sobre láminas de las que hoy no se conocen ejemplares. En estos casos se hace difícil establecer si se trata únicamente de pruebas inéditas, conservadas por el autor pegadas en las páginas de sus álbumes, o si las estampas han desaparecido, restando sobre ellas solo referencias escritas. ${ }^{\circ 0}$ Se completa este caudal de imágenes con acuarelas y dibujos a tinta que no llegaron a copiarse para su estampación.

Los Irigoyen abrieron hacia 1838 un gabinete óptico y negocio de estampas, llamado "Establecimiento Oriental Viaje de Ilusión-Litografía de Irigoyen", al estilo de los que funcionaban en Europa, en el que se exhibían estampas litográficas producidas por ellos, como las vistas de la actuación de la Compañía Gimnástica en la plaza

\footnotetext{
37 BERETTA GARCIA, Ernesto, "Antes del daguerrotipo", ob. cit.

38 Juan Manuel Besnes e Irigoyen (San Sebastián, Guipuzcoa, 1789-Montevideo, 1865) puede ser considerado el principal documentalista local de la primera mitad del siglo XIX. La diversidad de técnicas que practicó y su interés por traducir a imágenes acontecimientos de los que había sido testigo presencial, y el posterior pasaje a litografía de varios de ellos para consumo popular, le asignan un lugar preferencial en nuestro medio. Muchas de estas iniciativas las desarrolló con su hijo adoptivo, Ramón Irigoyen. Esta sociedad ha sido poco estudiada, pero a partir del material conservado puede ampliarse el conocimiento de su producción, que abarcaba también trabajos de carácter utilitario o administrativo, como formularios, títulos, etc.

39 BERETTA, Ernesto, Imágenes para todos, ob. cit.

$4^{\circ} \mathrm{La}$ ausencia de las estampas, pero las correspondientes fuentes escritas testimonian la pérdida de parte de esta producción. La fragilidad del material de soporte junto con la idea de ser obras con un valor esencialmente informativo o propagandístico, destinadas a circular, puede haber contribuido a su desaparición. Si consideramos que se tiraba un número elevado de ejemplares, pero actualmente se conservan exclusivamente como piezas únicas, entendemos la extinción de materiales irremplazables para el conocimiento del tema que nos ocupa.
} 
Constitución, o la serie titulada "Vistas del país", entre las que se encontraba un paisaje de la Aguada y una vista del molino de agua en Las Piedras, de las cuales no parecen haberse conservado ejemplares, al menos en los reservorios públicos revisados. Estas estampas implican el reconocimiento de los paisajes locales como válidos en sí para ser representados y difundidos, al igual que hacían los europeos con los suyos. $4^{1}$

La actividad de estos dibujantes-litógrafos y las colaboraciones entre artistas, estampadores e impresores, permitieron la generación de esta iconografía y una nueva forma de difundir las noticias, en muchos casos, con una intencionalidad a medio camino entre la documentación detallada, la propaganda política más o menos desembozada y el documento para la historia. Esta práctica sigue de manera incipiente un proceso similar al que se desarrollaba en Europa y en los Estados Unidos de Norteamérica, con la participación de artistas y estampadores reconocidos, -DurandBrager para el caso europeo, Currier and Ives para el estadounidense ${ }^{42}$, por ejemplo-, en la generación de materiales visuales para medios de prensa y estampas sueltas sobre asuntos de actualidad.

\section{Entre lo documental y lo publicitario.}

La difusión de estampas a partir de apuntes, bocetos o acuarelas realizadas por los artistas combinó aquellas vertientes que reproducían escenas de actualidad y retratos de personalidades del campo político, militar, social o cultural, hasta aquellas que decantaban hacia una mayor o menor tendenciosidad en el marco del conflicto regional. En muchos casos, determinar qué dimensión se trató de priorizar implica atender al contexto de publicación. Existen estampas, como la serie de tres momentos de los combates navales del 24 y 25 de mayo de 1841, realizadas por la Litografía de Irigoyen, en las cuales predomina lo documental, más allá de las connotaciones que las estampas reportaron para las autoridades del momento en cuanto a la difusión de la idea de creación de una armada nacional. A partir de las referencias escritas, vemos que sus realizadores eran totalmente partidarios del bando de Montevideo. Esta amplia

\footnotetext{
${ }^{41}$ BERETTA, Ernesto, Imágenes para todos, ob. cit.

42 Jean Baptiste Henri Durand Brager (Francia, 1814-1879) estudió pintura y realizó numerosos viajes por el mundo, reflejados en sus dibujos y apuntes. Trabajó como dibujante para $L$ 'Illustration francesa, enviado a la guerra de Crimea como corresponsal. Ver HOGARTH Paul, The artist as reporter, London, Studio Vista, 1967. Para las estampaciones de Currier and Ives, ver PETERS, Harry T., Currier \& Ives, Printmakers to the American People, Nueva York, Doubleday, Doran \&Co, Inc, 1943.
} 
variedad temática, abordada desde distintas perspectivas, la satírica, la publicitaria y la documental, no debe hacernos olvidar que el origen para todas las vertientes fueron episodios reales, en el marco de un contexto internacional extremadamente conflictivo.

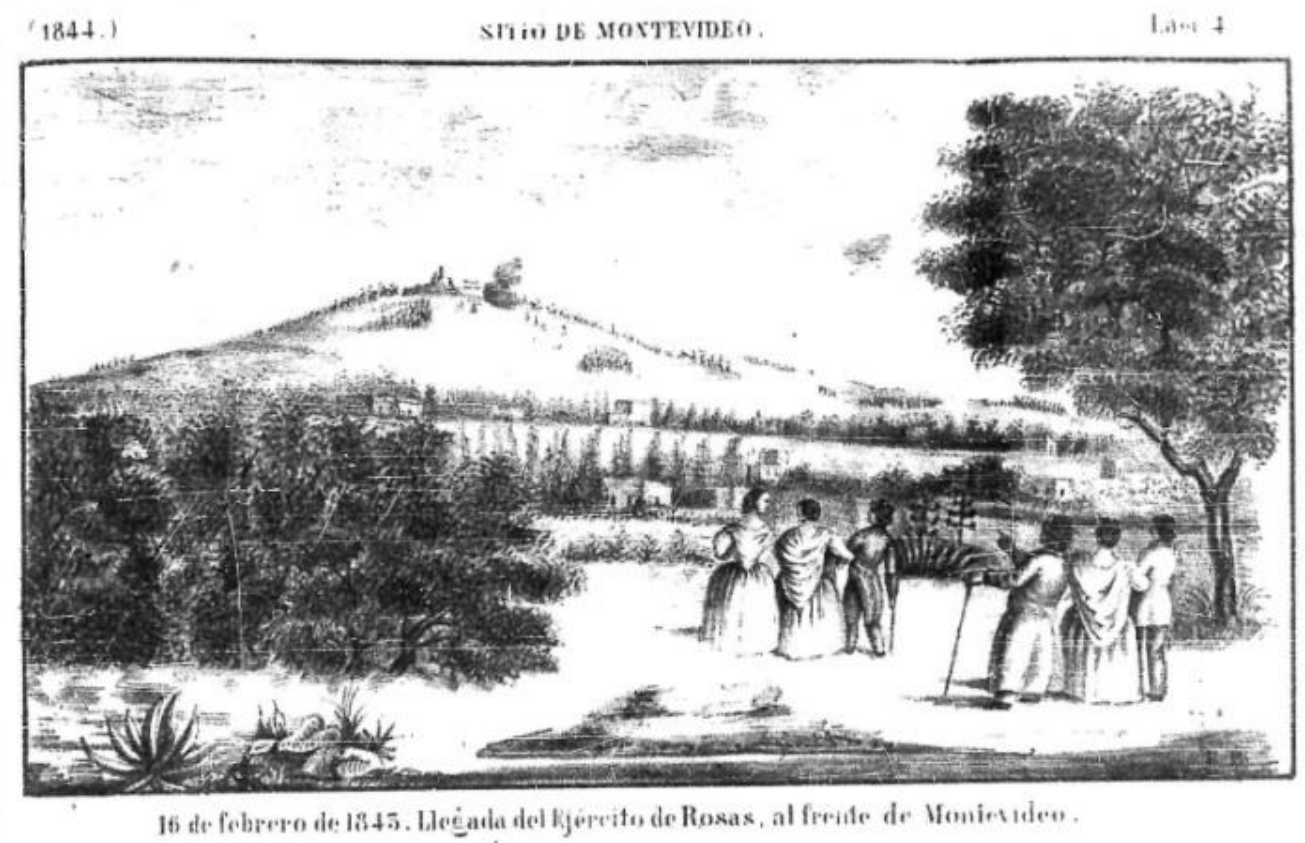

Foto 3: 16 de febrero de 1843. Llegada del ejército de Rosas al frente de Montevideo. Estampa litográfica de carácter documental, realizada por Erminio Bettinotti a partir de una acuarela de Besnes e Irigoyen, publicada en El Telégrafo de la Línea... Montevideo, Biblioteca Nacional.

Otras series, como la titulada, "Sitio de Montevideo" estampada por Besnes y Bettinotti43 para El Telégrafo de la Línea..., combinan esta vertiente documental con otras imágenes de carácter publicitario o alegórico. Siguiendo la costumbre de los artistas europeos, Besnes trabajaba en base a álbumes en los que iba realizando sus ilustraciones, pero también las complementaba con datos escritos, y apuntes diversos. La fuente para las litografías de El Telégrafo de la Línea... fue su álbum de acuarelas titulado "Episodios del Sitio de Montevideo", pero de la totalidad solo fueron traducidas a litografía algunas de ellas, las que resultaron más adecuadas a una publicación que propiciaba el aspecto publicitario y sesgado de las imágenes.

Las acuarelas de Besnes que refieren a acontecimientos de actualidad acompañadas de inscripciones y referencias sobre lo representado constituían la fuente

\footnotetext{
43 Erminio Bettinotti (hacia 1820-s/d), farmacéutico y litógrafo radicado en Montevideo. Partidario de la causa de la Defensa se alistó en la Legión Italiana. Junto a su actividad militar trabajó en la estampación litográfica, dados sus conocimientos de química. Las litografías que se han conservado con su firma destacan los aspectos publicitarios a favor del gobierno de Montevideo y los retratos de sus líderes.
} 
para posibles ilustraciones, y es de remarcar que contamos con folletos y libros en los que podrían haberse insertado.44 Podemos afirmar que Besnes generó un archivo personal de imágenes plausibles de ser traducidas a litografías u otra forma de estampación, cuando lo considerase conveniente o le fueran demandadas por los editores. En uno de sus álbumes se conserva una prueba litográfica en la que vemos la llegada de Fructuoso Rivera a la casa de gobierno en 1838.45 Allí, además de destacar al personaje, reflejó el bullicio popular que señala el respaldo que le ofrecía la población. La imprenta de la Caridad publicó el discurso que Rivera pronunció en esta ocasión. ${ }^{6}$ En el ejemplar consultado no figura esta litografía, pero habría sido perfectamente adecuada para la misma, o quizás el ejemplar era de los económicos, que se editaban sin la ilustración.

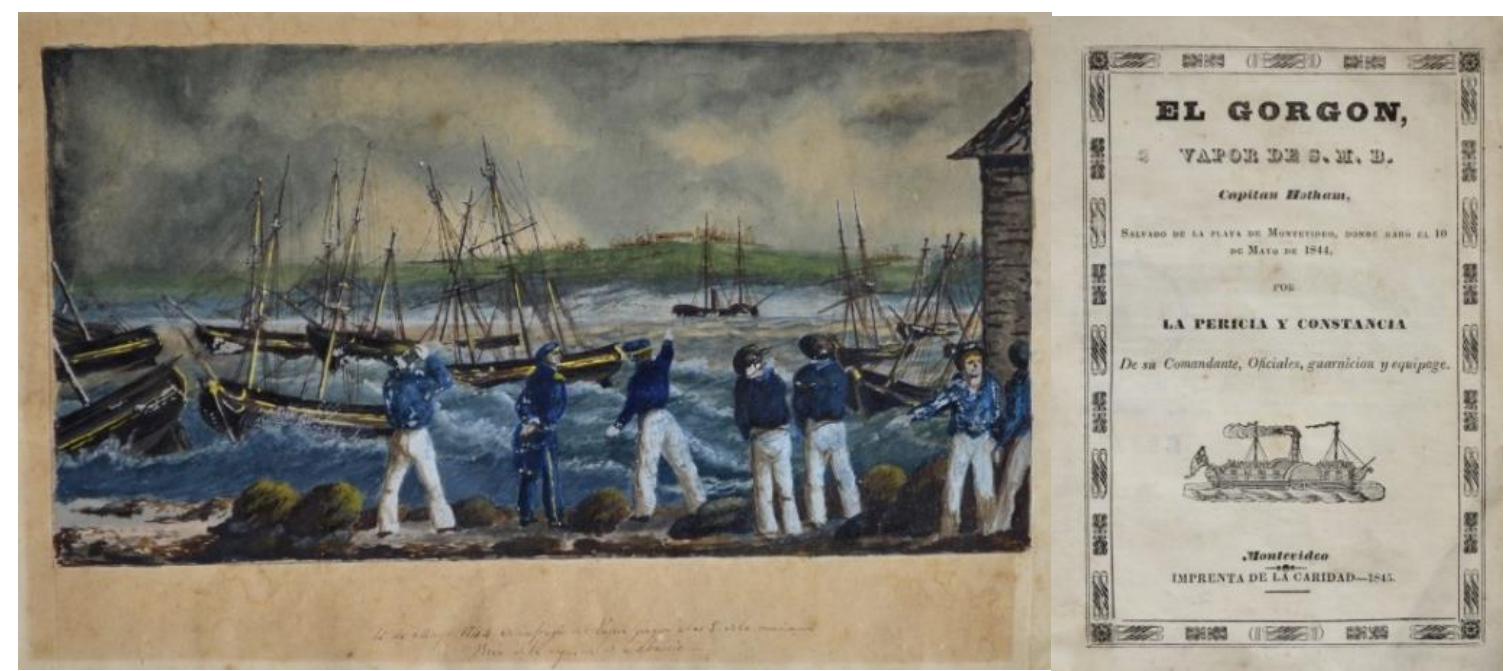

Fotos 4 y 5: Juan Manuel Besnes e Irigoyen, "Encallamiento del vapor Gorgon" y portada del folleto. Montevideo, MHN carpeta 1051 y MHN Biblioteca Americanista.

En las publicaciones ilustradas encontramos en algunos casos la separación de las ilustraciones y los textos, en lo que debemos considerar dos factores: el ya citado

44 Citemos dos ejemplos de asuntos de actualidad sobre los que contamos con imágenes (acuarelas) y textos impresos: el folleto titulado El Gorgon vapor de S. M. B. capitán Hotham, salvado de la playa de Montevideo donde baró (sic) el 10 de mayo de 1844, por la pericia y constancia de su Comandante, Oficiales, guarnición y equipage, Montevideo, Imprenta de la Caridad, 1845, podría haberse acompañado de la acuarela de Besnes "Encallamiento del vapor Gorgon" (MHN, carpeta 1431), pintada por el autor al presenciar la catástrofe. Esta situación se repite con el folleto Documentos oficiales relativos a los sucesos del 8 de noviembre de 1844 publicados por orden del Gobierno de la Republica, Montevideo, Imprenta del Nacional, 1845. También en este caso contamos con la acuarela de Besnes e Irigoyen titulada "La mañana del 8 de noviembre de 1844" (MHN 1431).

45 BESNES E IRIGOYEN, álbum "Prontuario de paisajes" ob. cit.

${ }^{46}$ Declaración del Exmo. Sr. General en Gefe [sic] del Ejército Constitucional D. Fructuoso Rivera, Hecha en los momentos de su entrada en la Capital de la República el 11 de noviembre de 1838, de los principios que han de guiarle en el desempeño de la alta misión que le está confiada, Montevideo, Imprenta de la Caridad, 1838. 
incremento del precio en aquellas publicaciones a las que se incorporaban imágenes, y las dificultades técnicas para insertar las imágenes entre las columnas de textos. Si para el primer caso citamos como ejemplo la publicación de un poema de Rivera Indarte, para el segundo citaremos al periódico La Defensa.47 Se trata de una de las últimas publicaciones del período en estudio, referidas al sitio de la ciudad y al enfrentamiento bélico, editada durante algunos meses de 1851 .

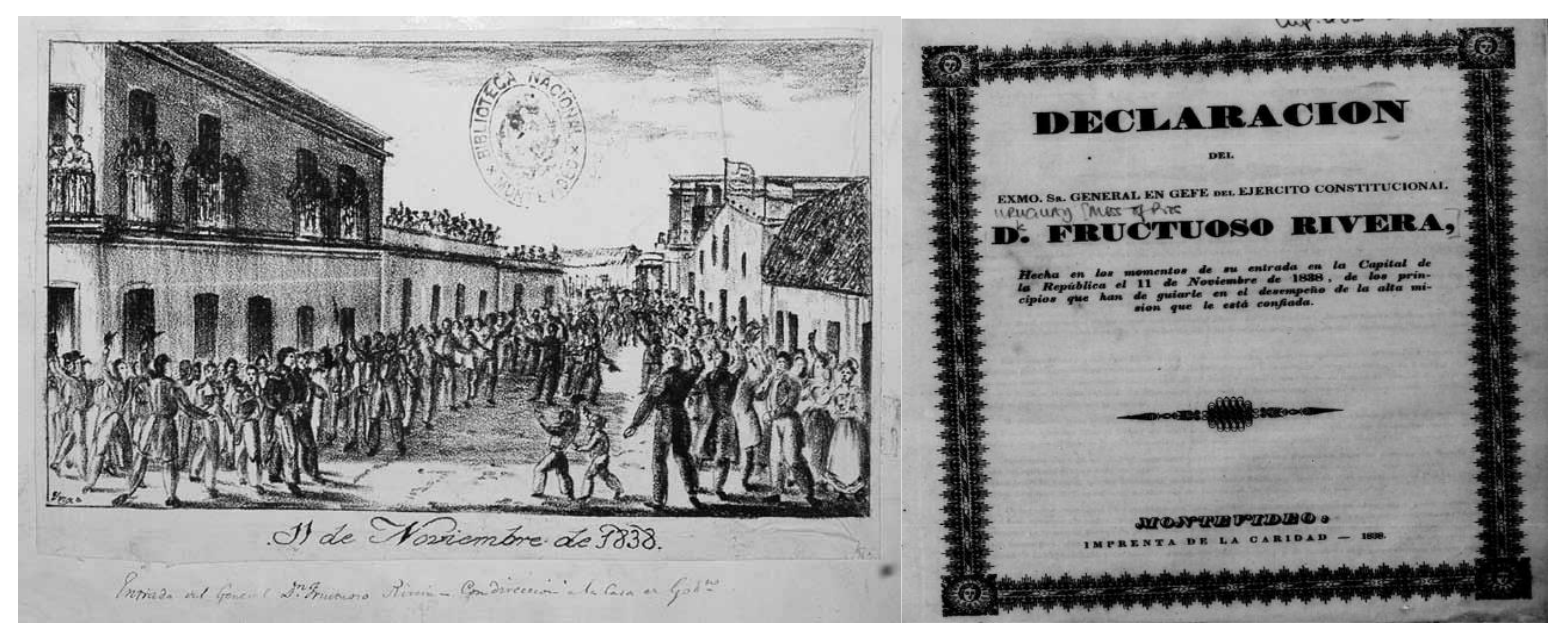

Fotos 6 y 7: Entrada de Fructuoso Rivera en Montevideo, en 1838, y portada del folleto con su discurso, dado al entrar en la capital, Montevideo, Biblioteca Nacional.

En sus páginas se publicó un folletín titulado Anales de la Defensa de la República, siguiendo un camino entre lo documental y lo publicitario. Este folletín llevaría diversos retratos de prohombres de la Defensa, sin embargo únicamente el primer retrato, el de Joaquín Suárez, se estampó en una página del folletín. El resto de los retratos se publicaron sueltos. Los interesados podían comprarlos para encuadernarlos con el folleto, una vez finalizada su publicación, o bien adquirir las láminas en forma independiente, que podían colgar en las paredes de su casa como reconocimiento a los defensores..$^{48}$ Esta costumbre de estampar los retratos de las personalidades del momento, fue también una vertiente tomada de las publicaciones europeas. Y fueron los mismos técnicos europeos radicados en Montevideo, conocedores de esta modalidad de representación, quienes la difundieron localmente:

\footnotetext{
47 La Defensa, ob. cit.

${ }^{48}$ En la Biblioteca Nacional, en Montevideo, se conservan dos colecciones de este periódico, una tiene las estampas, la otra no.
} 
Erminio Bettinotti litografió los retratos a tinta que había hecho de personalidades del gobierno de la Defensa.
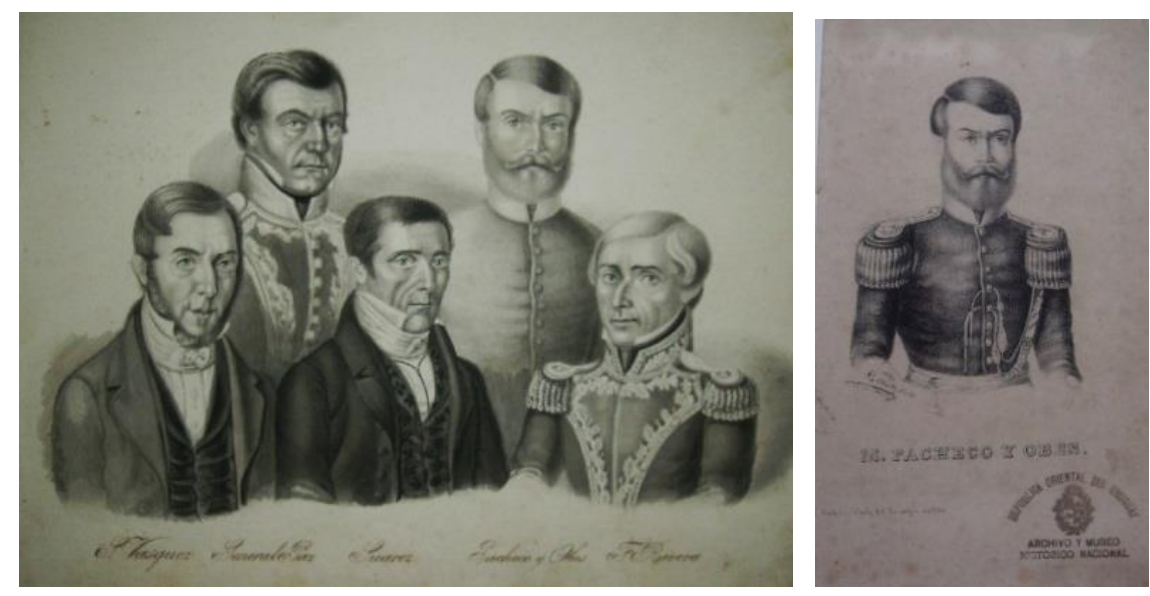

Fotos 6 y 7: Página del álbum Bettinotti, con retratos a tinta de Santiago Vázquez, José María Paz, Joaquín Suárez, Melchor Pacheco y Fructuoso Rivera. A la derecha, retrato de Melchor Pacheco, litografía sobre papel, 1843. MHN carpetas 2639 y archivo iconográfico.

\section{Las estampas sueltas}

Otra estrategia desplegada por los publicistas fue la de estampar hojas que se vendían sin ninguna vinculación formal a materiales escritos, es decir impresas de manera independiente. Los únicos textos o referencias aparecen en la misma lámina. Trata temas de actualidad, muchas veces en el marco de un documentalismo costumbrista, pero también atendieron a lo político y a lo militar. Las estampas de Ramón Irigoyen sobre las corridas de toros, realizadas en 1838, refieren a personajes reales, toreros conocidos por el público, y muy posiblemente a escenas ocurridas durante los ruedos, lo que implicaría que él mismo o Besnes hayan asistido, tomando los apuntes correspondientes. En estos casos se busca atraer la atención del observador mediante una escena atractiva y dinámica.

En estos casos, al igual que en las estampas insertas en periódicos anti rosistas y anti oribistas encontramos dos caminos. En algunas se hace presente la sátira, desmitificando a los sitiadores. Se conserva información sobre una estampa de Gielis, con motivo de la llegada frente a Montevideo de la escuadra de Buenos Aires, comandada por el Almirante Brown, en la cual se lo representaba como un gato viejo, alrededor del cual corrían pequeños ratones, representando a los marineros de la 
escuadra de Montevideo. La leyenda bajo la estampa era alusiva "Gato viejo no caza ratones". 49

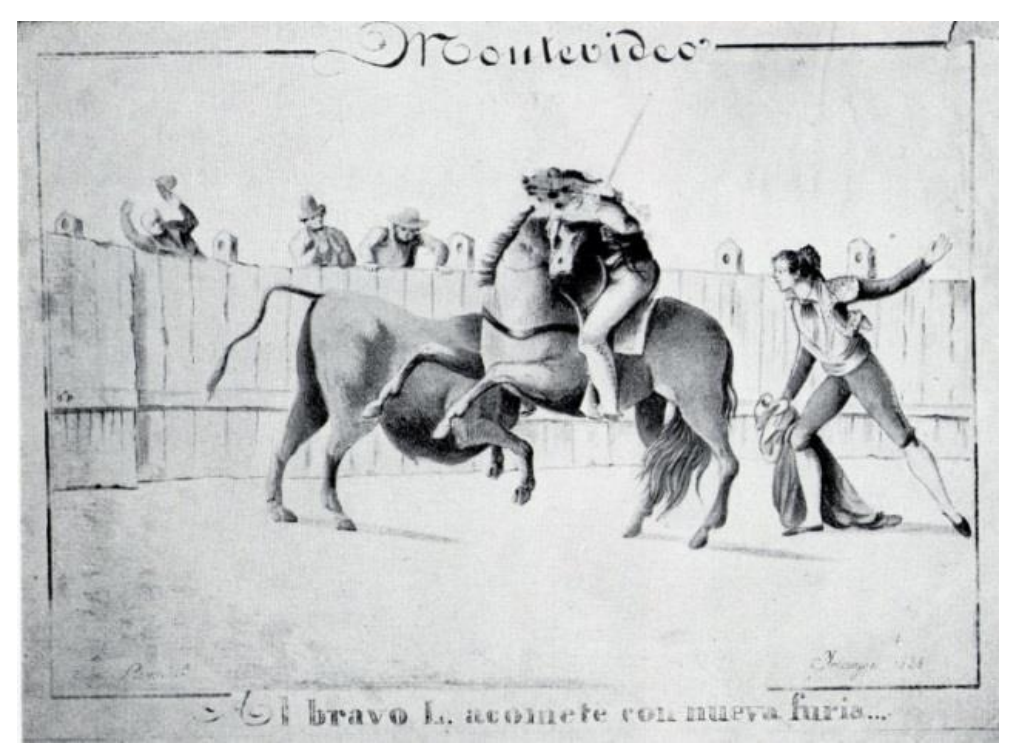

Foto 8: Tauromaquia montevideana. Estampa de Irigoyen, litografía sobre papel. MHN Montevideo, Casa de Lavalleja, Colección Pablo Blanco Acevedo, Carpeta Nro. 9, lámina 17.

Se conservan varias imágenes estampadas en forma independiente, y también contamos con variada información y descripciones sobre ellas. Generalmente su publicación parece haber sido iniciativa de los propios dibujantes-litógrafos, y se relacionan en general con acontecimientos de actualidad, exceptuando los paisajes. Los retratos de los presidentes constituyen un ejemplo de estas iniciativas, estampados con motivo de su ascenso a la primera magistratura (caso del retrato de Rivera por Carlos Risso, hacia 1830, y de Oribe por Gielis, 1836).

\section{Conclusiones}

El conjunto de factores técnicos y económicos que operó en Montevideo desde comienzos de la década de 1830 no explica por sí mismo la generación de las estampas y materiales impresos ilustrados. Fue la apertura de la comunidad intelectual y artística a las novedades europeas, su asimilación por el cuerpo técnico local y la receptividad de la población a sus mensajes y su soporte, lo que hizo posible la difusión de técnicas y estrategias publicitarias, permitiendo el ingreso de la sociedad oriental, al menos la

\footnotetext{
49 Referencias sobre esta estampa en diario El Nacional, Montevideo, 28 de julio de 1841, y en BERETTA, Ernesto, Imágenes para todos... ob. cit.
} 
urbana, a una cultura visual que podemos ubicar en la que Donald Lowe denominó cultura tipográfica, señalada por el predominio de la visualidad.50

El marco político de permanente conflicto desde mediados de la década de 1830 propició la utilización de las mismas como medio de crítica y propaganda, pero cumpliendo simultáneamente con documentar distintos acontecimientos y personajes del momento. Esta incorporación de imágenes a los periódicos siguió lo establecido por las publicaciones europeas y norteamericanas.

Resta por profundizar en el proceso de cambio en la cultura visual entre el período colonial y el período republicano, lo que implica conocer mejor cómo era la cultura visual colonial rioplatense, y que diferencias encontramos con la del período siguiente.

Fue en las primeras décadas de existencia del Estado Oriental que comenzó la producción autóctona de estampas y materiales ilustrados, dada la coexistencia de la imprenta con técnicas de estampación que permitieron obtener productos más cuidados desde el punto de vista técnico, con mayor riqueza visual e informativa.

De la instalación de esta nueva cultura queda como testimonio la presencia progresiva de imprentas y casas de litografía en la ciudad, que irán incrementando su número a lo largo del siglo XIX. El volumen de folletos, periódicos, diarios y estampas que se generó ya en la primera mitad del siglo y la existencia en plaza de los medios técnicos para producirlos estaría señalando también este cambio.

Las dificultades que tenemos para cuantificar la cantidad de imágenes disponibles para los montevideanos durante la primera mitad del siglo XIX, echan sombra en un aspecto del análisis, pero sí conocemos su utilidad como portadoras de información o pensamientos, cuya circulación se propiciaba. El interés de los editores por vincularse con los litógrafos, y su contratación frecuente (caso de Jaime Hernández con Gielis, y con Mège y Lebas), el interés de Florencio Varela por conocer las imprentas europeas y el intercambio de correspondencia entre los integrantes de la comunidad intelectual que deseaban tener un retrato del poeta Adolfo Berro para colocar en la portada del volumen que llevaría sus poesías, muestra lo candente que se

$5^{5}$ LOWE, Donald, Historia de la percepción burguesa, ob. cit. 
estaban volviendo las imágenes y los materiales impresos. La presencia de periódicos ilustrados -por lo menos cinco entre 1839 y 1851- señala la dimensión más popular en la difusión de ideas a través de imágenes.

También para la comunidad intelectual, adquirir dichas estampas se volvió un recurso valioso como forma de conservar registro sobre acontecimientos. La estampación del «Plano del glorioso Combate en los Campos de San Antonio, en el Salto; sostenido heroicamente por 250 defensores de la libertad, al mando del valiente Coronel Garibaldi, contra 1500 enemigos al mando de Servando Gómez», realizada por Gielis, y las estampas sobre los combates navales de 1841 y 1844, realizadas por los Irigoyen -y que fueron adquiridas por Andrés Lamas, fundador del Instituto Histórico y Geográfico-, muestran también el valor documental e histórico asignado a algunas de estas imágenes.

OOO

\section{Bibliografía}

ÁLVAREZ FERRETJANS, Daniel, Desde la Estrella del Sur a internet. Historia de la prensa en el Uruguay, Montevideo, Editorial Fin de Siglo, 2008.

AMIGO, Roberto, "Imágenes sitiadas. Tradiciones visuales y política en el Río de la Plata 1830-1870, en MERAo7, Memorias del encuentro regional de arte, tomo 2, Montevideo, 2009, pp. 59-75.

AMIGO, Roberto; "Carlos Morel. El costumbrismo federal". En Caiana. Revista de Historia del Arte y Cultura Visual del Centro Argentino de Investigadores de Arte (CAIA), № 3, Año 2013.

AZAROLA GIL, Luis "Un testamento de la época colonial" en Revista Histórica, publicación del Museo Histórico Nacional, año LIX ( $2^{\mathrm{a}}$ época), tomo XXX, nros. 88-90, Montevideo, Monteverde y Cía, 1960.

BERETTA, Ernesto, Imágenes para todos. La producción litográfica, la difusión de la estampa y sus vertientes temáticas en Montevideo durante el siglo XIX. Primera parte, de la constitución del Estado Oriental al fin de la Guerra Grande, Montevideo, Universidad de la República-CSIC, 2015. 
BERETTA, Ernesto, Mucho más que buena letra. El arte caligráfico en Montevideo durante el siglo XIX, Montevideo, Universidad de la República-CSIC, Editorial Fin de Siglo, 2011.

BERETTA, Ernesto, «Antes del daguerrotipo: gabinetes ópticos, cosmoramas, máquinas para sacar vistas y experimentaciones con los efectos de luz en Montevideo durante el siglo XIX», en Artículos de investigación sobre fotografía 2008, Montevideo, CMDF, 2009, pp.9-39.

DUARTE, Jacinto, Dos siglos de publicidad en la historia del Uruguay, Montevideo, 1952.

EICHENBERG, Fritz, Lithography and Silkscreen, art and technique, Nueva York, Harry N. Abrams, 1978.

ESTRADA, Dardo, Historia y bibliografía de la imprenta en Montevideo 1810-1865, Montevideo, Librería Cervantes, 1912.

FERNÁNDEZ y MEDINA, Benjamín, La imprenta y la prensa en Uruguay desde 1807 á 190o, Montevideo, Imprenta de Dornaleche y Reyes, 1900.

FERRO, Gabo, Barbarie y civilización, sangre, monstruos y vampiros durante el segundo gobierno de Rosas, Buenos Aires, Editorial Marea, Colección Pasado Imperfecto, 2008.

FÜKELMAN, María Cristina, «La construcción de un tipo iconográfico: la figura de Juan Manuel de Rosas en la prensa opositora: caricatura y sátira en la prensa antirrosista», en Anuario del Instituto de Historia Argentina, año VI, Universidad de La Plata, Facultad de Humanidades y Ciencias de la Educación, La Plata, 2006, pp. 97-124.

FURLONG, Guillermo, Historia y bibliografia de las primeras imprentas rioplatenses 1700-185o, (3 tomos), Buenos Aires, Editorial Guarania, 1953.

FURLONG, Guillermo, La Imprenta de la Caridad (1822-1855), Montevideo, El Siglo Ilustrado, 1932.

GONZÁLEZ DEMURO, Wilson, "El sol de las Provincias Unidas, un comentario sobre el periodismo, la revolución y la difusión de ideas en Montevideo a fines de la época colonial", en CLAHR, Colonial Latin América historial review, vol. 13, $\mathrm{n}^{\circ}$ 1, Albuquerque, 2004 (2006), pp. 53-87.

GONZÁLEZ DEMURO, Wilson, “Un juez severo al que temen aún los gobiernos más despóticos. El concepto de opinión pública en la prensa oriental durante la 
revolución (1810-1820)" en Humanidades. Revista de la Universidad de Montevideo, No XII, Montevideo, 2013, pp. 97-124.

GONZÁLEZ DEMURO, Wilson, "La historiografía de la prensa periódica en Uruguay (1880-2010) Perfiles, avances y asuntos pendientes”, en Chasqui, Revista Latinoamericana de Comunicación. Disponible en: www.revistachasqui.org/index.php/chasqui/article/view/434/433

GRÜNWALDT RAMASSO, Jorge, Vida, industria $y$ comercio en el antiguo Montevideo 1830-1852, Montevideo, Barreiro y Ramos, 1970.

GUTIERREZ, Ramón (coord.), Pintura, escultura y artes útiles en Iberoamérica, 1500-1825, Madrid, Arte Cátedra, 1995.

HERAS, Carlos, Orígenes de la imprenta de Niños Expósitos con una introducción sobre «Los primeros trabajos de la imprenta de Niños Expósitos», La Plata, Publicaciones del Archivo Histórico de la Provincia de Buenos Aires, Documentos del Archivo, Tomo x, Taller de Impresiones Oficiales, 1943.

HOGARTH Paul, The artist as reporter, London, Studio Vista, 1967.

LOWE, Donald, Historia de la percepción burguesa, México, FCE, 1986.

MAGARIÑOS DE MELLO, Mateo, El Gobierno del Cerrito, Montevideo, 1953.

MALOSETTI COSTA, Laura, "Exilios, revistas y cuadros en el origen de un sistema artístico moderno en la región", en MERAo7, Memorias del encuentro regional de arte, tomo 1, Montevideo, 2009, pp. 84-97.

PETERS, Harry T., Currier \& Ives, Printmakers to the American People, Nueva York, Doubleday, Doran \&Co, Inc, 1943.

ROMÁN, Claudia, «Caricatura y política en El Grito Argentino (1839) y iMuera Rosas! (1841-1842)», en Gabriela, BATTICUORE, Klaus GALLO y Jorge MYERS (comp.): Resonancias románticas, Ensayos sobre historia de la cultura argentina (1820-189o), Buenos Aires, Eudeba, 2005, pp.49-69.

SPERONI VENER, Julio, «Noticias bibliográficas. Un folleto raro de Ascasubi: la edición original del Paulino Lucero», en Revista Histórica, Publicación del Museo Histórico Nacional, Año LIV, $2^{\text {a }}$ época, tomo XXX, Nros. 88-90, pp. 510543, Montevideo, Monteverde y Cía., 1960.

UGARTECHE, Félix de, La imprenta argentina. Sus orígenes y desarrollo, Buenos Aires, Talleres Gráficos R. Canals, 1929.

VICARY, Richard, Manual de Litografia, Madrid, Hermann Blume, 1986. 
ZINNY, Antonio, Historia de la prensa periódica de la República Oriental del Uruguay, 1807-1852, Buenos Aires, Imprenta y Librería de Mayo, 1883.

\section{Fuentes}

A Miguel de Cervantes Saavedra Príncipe de los Ingenios Españoles, Montevideo, Imprenta Oriental, 1838.

ASCASUBI, Hilario, Paulino Lucero ó dos gauchos en Entre Ríos, Montevideo, Imprenta Hispano-Americana, 1846.

ASCASUBI, Hilario, La encuetada ó los gauchos y la intervención en el Río de la Plata, Montevideo, 1848.

Biblioteca Dramática, Selecta y escojida [sic] de las mejores piezas del teatro moderno. La Marcela y El Trovador, Autores Sr. Bretón de los Herreros y D. A. G. Gutiérrez, Montevideo, Imprenta de la Caridad, 1837.

Catálogo de los libros ecsistentes (sic) en la librería de Jaime Hernández, Diciembre 4 de 1837, Calle de s. Pedro junto a la sala de comercio, No 1, Montevideo, Imprenta de la Caridad, 1838.

Declaración del Exmo. Sr. General en Gefe [sic] del Ejército Constitucional D. Fructuoso Rivera, Hecha en los momentos de su entrada en la Capital de la República el 11 de noviembre de 1838, de los principios que han de guiarle en el desempeño de la alta misión que le está confiada, Montevideo, Imprenta de la Caridad, 1838.

Documentos oficiales relativos a los sucesos del 8 de noviembre de 1844 publicados por orden del Gobierno de la Republica, Montevideo, Imprenta del Nacional, 1845 .

DOUVILLE, Jean Baptiste, 30 mois de ma vie, ou quinze mois avant et quinze mois après mon Voyage au Congo, accompagné de pièces justificatives, de détails nouveaux et curieux sur les mœurs et les usages des habitans du Brésil et de Buenos-Ayres, et d'une description de la colonie Patagonia, París, 1833.

El Gorgon vapor de S. M. B. capitán Hotham, salvado de la playa de Montevideo donde baró (sic) el 10 de mayo de 1844, por la pericia y constancia de su Comandante, Oficiales, guarnición y equipage (sic), Montevideo, Imprenta de la Caridad, 1845 .

VARELA, Florencio, "El diario de viaje inédito de Florencio Varela por Inglaterra y Francia (1843-1844)” en Revista Histórica publicación del Museo Histórico 


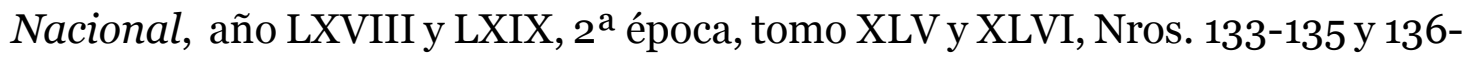
138, Montevideo, 1974, 1975, pp. 195-379 у 245-406.

\section{Álbumes}

BETTINOTTI, Erminio, “Álbum Bettinotti”, Montevideo, MHN.

BESNES E IRIGOYEN, Juan Manuel, “Álbum chico”, "Prontuario de Paisajes”, "Viaje a la Villa del Durazno” en Obra de Besnes e Irigoyen en Biblioteca Nacional, Montevideo, Biblioteca Nacional, 2004 (edición en dos CD). Disponible en: http://bibliotecadigital.bibna.gub.uy:8080/jspui/handle/123456789/5

“Episodios del sitio de Montevideo” (reproducción fotográfica, MHN).

GORE OUSELEY, William, Description of views in South America from original drawings made in Brazil, the River Plate, the Paraná, lithographed by Needham, London, Thomas Mc Lean, 1852.

MOREL, Carlos “Usos y costumbres del Río de la Plata”, Buenos Aires, 1844.

Poesías de D. Adolfo Berro. Montevideo, Imprenta del Nacional, 1842.

\section{Prensa}

Comercio del Plata, Montevideo, Buenos Aires, 1845 - 1860.

El Grito Argentino, Montevideo, Imprenta de La Caridad, 1839.

El Tambor de la Línea, Montevideo, 1843.

El Telégrafo de la Línea. Semanario de guerra y del ejército. Unión y Libertad, Montevideo, Imprenta de la Caridad, 1844-1845.

Gazeta de Montevideo, Colección Biblioteca de impresos raros americanos, volumen 1 (1810 octubre-diciembre), volumen 2 (1811 enero-junio), Montevideo, Universidad de la República, Facultad de Humanidades y Ciencias, Instituto de Investigaciones Históricas, 1948 y 1954.

Instituto Histórico y Geográfico del Uruguay, The Southern Star / La estrella del Sur, Montevideo 1807, reproducción facsimilar, Montevideo, Barreiro y Ramos, 1942.

La diablada o el robo de la bolsa, Montevideo, Imprenta de la Libertad, 1832.

La Defensa, Montevideo, Imprenta Francesa, 1851

MADRAZO, Federico y OCHOA, Eugenio (ed), El artista, Madrid, Imprenta de I. Sancha, 1835-1836.

Muera Rosas! Periódico semanal. Patria! Libertad! Constitución!, Montevideo, Imprenta Constitucional, 1841- 1842. 